\title{
The First Vajpayee Government: Golden Years of Non-Military Confidence Building Measures between India and Pakistan
}

\author{
Layaslalu $\mathrm{M}$ \\ (Research Scholar, Centre for South Asian Studies, Pondicherry University, India)
}

\begin{abstract}
Since the very outset of their formation, politics has always been crucial and conflict ridden between India and Pakistan. In the long seven decades of political history of India and Pakistan, there has been countless diplomatic strategies including both military and non-military confidence building measures to reinstall faith and peace between India and Pakistan. Focusing on the multifarious non-military confidence building measures introduced by the first A.B Vajpayee Central Ministry of India, this paper goes on to argue that the tenure of A.B Vajpayee ministry (1998-2004) was the golden years that witnessed the full-fledged activity of the diplomatic mechanism between India and Pakistan. The paper differentiates A.B Vajpayee ministry from the other Indian governments in its enthusiasm in reinstating peace between India and Pakistan through the non-military confidence building measures such as summits, sports diplomacy, and ceasefire agreements and so on. This paper exclusively centering on the A.B Vajpayee ministry (1998-2004) also examines the relevance of non-military confidence building measures as opposed to the military confidence building measures in improving bilateral relations between the neighbor countries.
\end{abstract}

Keywords: A.B Vajpayee, diplomacy, India, Non-military Confidence Building Measures, Pakistan.

\section{INTRODUCTION}

Political rivalries between modern nation states are quite a universal phenomenon especially between the countries those have a shared common past with similar, yet, painful histories of partition or new state formation. The relationship between India and Pakistan, an excellent example of the said case, speaks of seven decade long saga of hostility, rivalry and conflicts than about friendship and cooperation. Apparently, the conflicts had started since the inception of the two independent countries; both formed in 1947 after the independence from British India and the subsequent partition. During the seven decades of the history of India and Pakistan, there were three major wars and unending disputes over the territory of Kashmir leading to strong contentious political climate between India and Pakistan. The seven-decade long legacy of the cross-border disputes between India and Pakistan set on fire immediately after the partition of erstwhile British India has witnessed three major wars and numerous battles, proxy wars, infiltration issues and territorial disputes. Looking back after long seventy years, the India-Pakistan relations, and hence the South Asian political scenario, was most often intermittently marred by cross-border conflicts and border battles. From the very outset, the Kashmir issue has been the major irritant that spoils all the peace efforts between India and Pakistan. Even though rivalry and conflicts are very common, and perhaps inevitable between both states, this paper highlights some of the significant aspects of the Confidence Building Measures (CBMs), especially the Non Military Confidence Building Measures including bilateral talks, cultural and academic exchanges, trades, sports, and transportations and so on that are very crucial in establishing the peace between India and Pakistan. In this specific context, this paper closely examines the attempts made by the Vajpayee-led first NDA government (1999-2004) in bringing about strategic diplomatic peace between India and Pakistan. The A.B Vajpayee government stands out unique among other Indian governments in handling the international relationship with Pakistan. The multifarious means of confidence building measures, diplomatic moves, strategic policy decisions, peace initiatives, the former Prime Minister A.B Vajpayee has employed in smoothening the relations of India with Pakistan, as opposed to other Indian governments, has turned the issue into something of international significance. Hence, this paper would study the various confidence building measures, especially those of the non-military approach, introduced by A.B Vajpayee government in improving India-Pakistan relations.

Though there has been a good number of previous research work in the area of India-Pakistan international relationship, the focus and scope of various research publications has been variously different. For instance, Parvaiz Iqbal Cheema (2012), in his article deals with the India Pakistan relations and the factors which encourage and discourage their relations. In his yet another article, titled "Analyzing the Pakistan-India Peace Process: Pakistan Horizon" (2007), Parvaiz Iqbal Cheema analyses the India and Pakistan peace process and the factors which sustained and slowed down the relations. Cheema points out that though there were 
number of good times for being a friendly relations the unexpected incidents and the following decisions of the leaders has halted the peace process. He stresses the importance of Nonmilitary Confidence Building Measures and people to people contact in the Indo-Pak peace process. Regarding the issue of Confidence Building Measures, the report of the Secretary General of UN Centre for Disarmament (1982), titled "Comprehensive study on Confidence Building Measure", has mentioned about a comprehensive study on Confidence Building Measures (CBMs) in the $33^{\text {rd }}$ session of UN general assembly in 1978. The session has found out that though there are lot of military CBMs prevailing in the world but the situation remains the same. The report advocates for the practice of Non-Military CBM which can positively contribute to ensure international peace and stability. The report focuses on the need to effectively implement a concrete base only through which an effective CBM is possible. Yet another article on Confidence Building Measures, The Guide on Non-Military CBM: "Organization for Security and co-operation in Europe' briefly discusses the Non-Military CBM and its nature characteristics, limitations and pitfalls that are considered while designing CBM.Usman Altaf, in his article on India-Pakistan international relations titled "Pakistan India Relations need of CBMs and peace process", mentions the need for CBMs between India and Pakistan. He argues that many agreements signed between India and Pakistan has resulted in failure due to the short sighted view, poor implementation and political deference of both country. The nuclear capability and internal problems of Pakistan has opened more opportunity for CBM between India and Pakistan. The effective and mutual conversation only can make possible to avoid the distrust among these countries. Umbreen Javaid (2010), in his article titled "Confidence Building Measures in Nuclear South Asia: Limitations and Prospects", discusses the nuclear threat in South Asia due to India-Pakistan conflicting relationship. He states that the South Asian CBMs experiences is not much better even though there exist lots of CBMs between nations for the poor political willingness and lack of real spirit for resolving the issues. According to Umbreen Javed, it is a must to improve a conscious effort to make a mutually beneficial trade driven by economic forces.

Mutahir Ahmed, in his article titled "The Role of Confidence-Building Measures: Indo-Pakistan Conflicts" (1995), deals with the importance of the CBM between India and Pakistan to resolving the historical hostility. It need time, patience and conscious and constant effort and more over a political will. The article draw out the importance of Non-Military CBM rather than Military CBM.

In a bird's eye view, among the research publication, articles, books and documents published in the area of Confidence Building Measures between India and Pakistan, something that grasps immediate attention is that almost all studies deal with the concept of Confidence Building Measures only on an overall but comprehensive outlook. Very rarely had there been works that differentiate the non-military and military confidence building measures adopted in solving the India-Pakistan Border Crisis. This article, as opposed to the rest of the publications in this area, differentiates non-military confidence building measures from military confidence building measures, giving a special attention to the former approach in peace initiatives. Apart from the other articles dealing with the India-Pakistan issue, this paper singles out A.B Vajpayee ministry (19992004) of India in their remarkable enthusiasm in seeking for a permanent solution for India-Pakistan territorial dispute, especially, Non Military Confidence Building Measures including Lahore summit (1999), Agra summit (2001), cultural and academic exchanges, trade, sports, and transportations that are crucial in establishing the peace between India and Pakistan. Thus, in a nutshell, this paper is a pertinent attempt in the field of international relations as it seeks out to unravel the significance of the non-military confidence building measures initiated by the first NDA government in India under the Prime Ministership of A. B Vajpayee in order to improve the bilateral relations with the neighbor country Pakistan.

\section{CONFIDENCE BUILDING MEASURES (CBMS)}

Confidence Building Measures (CBMs), an important component in the international peace process, witnessed its systematic development as a diplomatic measure in the international relations in the second half of the $20^{\text {th }}$ century. "At its 33rd session, the General Assembly adopted resolution 33/91 B of 16 December 1978 under the item entitled "General and complete disarmament", in which it recommended consideration of confidence building measures and invited all States to inform the Secretary General of their views and experience on confidence building measures". ${ }^{1}$ Earlier, the $10^{\text {th }}$ session had concluded the final objective of CBMs, which was to strengthen international peace and stability. Confidence Building Measures (CBMs) are essentially designed to increase mutual understanding by reducing suspicions. "They are separable into military and non-military Confidence Building Measures and into those having a unilateral, bilateral or international content. Military Confidence Building Measures are also classifiable into transparency, communications and

${ }^{1}$ U.N.Report of the secretary General, 1998, pp.1.

\begin{tabular}{lll}
\hline DOI: $10.9790 / 0837-2204053139$ & www.iosrjournals.org & 32 Page
\end{tabular}


constraint measures to perform the related functions of information, notification, observation and stabilization. Confidence Building Measures (CBMs) can further be catalogued into provisions enabling information exchange, mutual access to observation or arrangements to handle incidents and crises",. ${ }^{2}$ They could be very useful in minimizing international tensions, avoiding conflicts and Confidence Building Measures (CBMs) could even lead to co-operation and peace between rival groups. Confidence Building Measures (CBMs) cannot solve any issue directly but it will help set up an amicable atmosphere for conversation and co-operation among the rival groups. Non-Military Confidence Building Measures are the processes or actions undertaken in all the phases of the conflict cycle across the three dimensions of the security in political, economic, social and cultural field with the aim of increasing transparency and confidence between two or more conflicting groups to pave the way for lasting solutions. Aiming to achieve a sustainable peace in times of crisis, Confidence Building Measures bring people together as a necessary pre-requisite for establishing confidence among the parties involved.

The non-military Confidence Building Measures (CBMs) has helped in reducing the tensions and rivalries among the rival groups by providing a wider opportunity to engage with each other in a friendly manner. The Confidence Building Measures have very significant role in providing a platform for discussions and cooperation between India and Pakistan.

\section{INDIA-PAKISTAN RELATIONS AND INDIAN GOVERNMENTS OVER DECADES}

Beginning with the first Central Ministry of India headed by Jawaharlal Nehru that assumed office on 15 August 1947, there have been innumerable diplomatic measures and peace talks initiated by India attempting for a peaceful settlement of the post-partition differences with Pakistan. The Indo-Pakistan War of 1947-1948, popularly known as the First Kashmir War, over the decision of the princely state of Kashmir and Jammu to join Indian nation was the first notable event that marked the disrupted peace at the borders. Thereafter, there had been two major wars between India and Pakistan at the borders, one in 1965 and another in 1971. In 1965, the second India-Pakistan war broke out following continuous ceasefire violations at the borders, when India, under the Prime Ministership of Lal Bahadur Shastri, was armed up to defend and protect Ran of Kutch from the Pakistan attempt to conquer the same. In 1971, when the Pakistan attacked India at the Kashmir borders opposing the latter's pro-East Pakistan standpoints, the Indian Prime Minister Indira Gandhi opened up a fullfledged war against Pakistan resulting in declaring Bangladesh, the erstwhile East-Pakistan an independent new nation. Quite a notable aspect of the above historical events is that the Indian National Congress led Indian governments had always held an iron hand policy in the matter of disputes and conflicts with Pakistan. After the defeat and loss of territory in the India-Pakistan War of 1971 Pakistan gave up the efforts of direct conflicts and wars with India and resorted to infiltrations, border disputes and constant ceasefire violations in the IndiaPakistan border region in order to generate a general opinion that Kashmir is a constant conflict-ridden region. In 1977, when Morarji Desai attained Indian Premiership he avowed to stop all armed moves against Pakistan in the Indian borders. The 1980s witnessed Indira Gandhi's return to power when she continued to wage an iron hand against Pakistan. Most of the Indian governments that assumed office following Indira Gandhi's death in 1984 were short-lived. Next notable efforts in the area of India-Pakistan dispute solving comes to play when P.V Narasimharao heads the Indian government in 1991. For the first time realizing the threat of terrorism, P. V Narasimharao initiated nuclear security measures and raised the annual budget allocations for defense purposes. After three short-lived Central ministries, India had a strong and standing full-term serving Central government led by A.B Vajpayee in 1999.

During the tenure of the then Prime Minister of India, Atal Bihari Vajpayee (1998-2004), there were unprecedented series of efforts from the side of India to maintain a cordial relationship with Pakistan. Unlike the other Indian Prime Ministers, Vajpayee was more visionary and vibrant in building peace at the borders as the facts and evidences regarding the non-military Confidence Building Measures engagements with Pakistan show. He realized the importance of cooperation rather than confrontation between India and Pakistan which is the crying need of the time. He initiated many unilateral initiatives to engage with Pakistan for better friendly relations. This article will examine and evaluate various non-military Confidence-Building Measures initiated between India and Pakistan during the tenure of the former Prime Minister AtalBihari Vajpayee's first NDA (National Democratic Alliance) government, from 1999 to 2004.

\section{A.B VAJPAYEE MINISTRY AND NON-MILITARY CONFIDENCE BUILDING MEASURES}

\footnotetext{
${ }^{2}$ Mohammed Badrul Alam, 2010, pp.41.
} 
The year 1998 was crucial for both the countries for, in this year both emerged as a nuclear power after their successful nuclear experiments. Moreover, the entry of these prominent countries into the nuclear club increased the existing tension at the respective national borders and inevitably it took the issues to more problematic dimensions from decades-long border issues to new threats. The peace and security of the Indian subcontinent is highly depended on how India and Pakistan would deal with their strained relationship. Since the nuclear developments in India and Pakistan, the South Asian region had become a scenario of potential nuclear threat. The nuclearisation added further worries to the hostility between India and Pakistan. These developments carved the South Asian region to be the most volatile subcontinent and, turned the relation between India and Pakistan more critical. Hence, it is important to take a look at the impact of the nuclear tests on the process of dialogue between the two states. "In a climate of newly created tensions and suspicions, in the wake of nuclear tests by India and Pakistan, both countries felt the need to talk to each other at sufficiently high levels to find a meeting ground and to instill mutual confidence', 3 This was the political context in which the first NDA government was sworn in India under the leadership of Prime Minister A.B. Vajpayee. Though he was responsible for the nuclear experiment the previous year, from 1999 onwards the government had implemented a series of peace initiatives or the non-military Confidence Building Measure.

\subsection{DELHI-LAHORE BUS DIPLOMACY}

The Delhi Lahore bus service, a passenger bus service between India and Pakistan, connecting the Indian capital city of Delhi and Pakistan city of Lahore was a hopeful start to a new history. "The Bus service originally intended to enhance people to people contact between India and Pakistan was first agreed up on during the meeting held between Pakistani Prime Minister Nawaz Sharif and Prime Minister Vajpayee in New York in September1998', ${ }^{4}$ On the occasion of the inaugural run of the bus service from Delhi to Lahore on February 19, 1999, Indian Prime minister A.B.Vajpayee made a historical and landmark visit to Pakistan. "He was the first Indian Prime Minister to visit Pakistan since Rajeev Gandhi's visit in 1989. While the first ever Prime Minister of India to visit Lahore since Nehru's visit in 1951".

The Lahore bus diplomacy had contributed to alleviate the tension between India and Pakistan arising from the nuclear experiments executed by both the countries in 1998. The bus service has facilitated the rejoining of the separated families of both countries and also promoted the economic and cultural connections beyond the borders. The cultural and economic contacts strengthen the faith between the peoples of the two hostile countries. The inauguration of the Delhi and Lahore bus service and Vajpayee's visit have reinforced the mutual cultural affinity between India and Pakistan. Many eminent Indians from the fields of film, art, culture and cricket who had accompanied Vajpayee includeShatrughan Sinha, Mallika Sarabhai, ArunShourie, Javed Akhtar, Satish Gujral, KuldipNayar and Kapil Dev. Such diplomatic moves ensured the cultural affinity between India and Pakistan whereby the bilateral peace-terms could be achieved and the trust between India and Pakistan could be replaced. The Delhi-Lahore bus that conveyed traders, diplomats and celebrities from and to both the countries was operated even in the worst situations of Kargil outbreak. However, later, "the Indian Government has decided to halt the service as part of diplomatic steps to make Pakistan crackdown against militants blamed for the attack on parliament in Delhi". ${ }^{6}$ On July 11, 2003, the bus was resumed by the peace initiation taken by Vajpayee.

Considering the far-sighted vision of A.B Vajpayee that war is not an option, but mutual cooperation is the finest means to retain the peace for India and Pakistan, the Delhi-Lahore bus diplomacy remains a sign of the desired friendship and people to people contact between India and Pakistan. The bus trip and the subsequent development in the field of cooperation and composite dialogues were expected to reopen a new era in the relations between the two countries.

\subsection{LAHORE DECLARATION}

The Lahore Declaration was a bilateral agreement between India and Pakistan signed on February, 21, 1999 by the then Indian Prime Minister AtalBihari Vajpayee and his Pakistan counterpart Nawaz Sherriff at the conclusion of the historic Lahore summit. It was the first major political agreement between India and Pakistan since the Shimla agreement in 1972. The Lahore Declaration was historically very significant for Vajpayee was the first Prime Minister to visit Lahore since Jawaharlal Nehru had paid a visit to Lahore in 1951. The Lahore summit was significant in the development of a bilateral relation in the context of the nuclear advancements in India and Pakistan. The historic Lahore summit provided a crucial opportunity for the discussion on all the

\footnotetext{
${ }^{3}$ Satpal, 2014, pp.1.

${ }^{4}$ Sumita Kumar, 1999, pp.167.

${ }^{5}$ Amjad Abbas Maggsi, (n-d), pp.190.

${ }^{6}$ Ayanjit Sen, BBC News. December 28, 2001.

DOI: $10.9790 / 0837-2204053139 \quad$ www.iosrjournals.org $\quad 34 \mid$ Page
}


outstanding issues between the two countries including Kashmir at the highest political level. The declaration brought about a major breakthrough in overcoming the strained bilateral relations between the two countries since the two leaders had given up their traditional stand on Kashmir issue.

On February 21, 1999, at the Governor's house in Lahore, both the Prime Ministers expressed their readiness to move beyond their traditional political standpoints to find a stable solution for the Kashmir issue between India and Pakistan. The strained relationship between India and Pakistan became normal after Indian Prime Minister A.B. Vajpayee had signed the declaration at Lahore summit in 1999. "Both the countries committed themselves to intensify their efforts to resolve all dispute issues, including the Jammu \& Kashmir dispute, refrain from intervention and interference in each other's internal affairs and to take some Confidence-Building Measures (CBMs) in the nuclear and conventional military fields". 7

The Lahore summit gave more importance to peace and prosperity of the people. Both the Premieres shared the vision of the mutual cooperation and goodwill of their people. Most of the outcome of the summit was characterized by the cultural, political and social relations than military relations. "While addressing a joint press conference, the two Premiers expressed their satisfaction on the commencement of bus service between Delhi and Lahore". ${ }^{8}$ The inauguration of the bus service was the first attempt in the India-Pakistan peace building process which fulfilled the wishes of the people of the two country. The Lahore summit emphatically underlined the realization of both Indian and Pakistani Prime Ministers that people-to-people contact is the best means to minimize the suspicions in the minds of the people of the two hostile countries.

Daring the opposition from India, the then Prime Minister A B Vajpayee strengthened bilateral cultural relationship with Pakistan visiting cultural monuments there. During his historic journey to Lahore, Vajpayee visited Minar-i-Pakistan and tombs of Allama Iqbal and Ranjeet Singh. His visit, especially, to Minar-iPakistan, a highly symbolic gesture, was a brave decision by which Vajpayee won the hearts of the Pakistani people. He ensured the real intention of the visit that India is not an enemy but a friend which supports peace and prosperity of Pakistan. The visit was marked as one of the greatest cultural contacts between India and Pakistan. It proved India's respect towards the emotions of millions of Pakistani people.

The two Premiers have restrained their hatred propaganda through state controlled media against each other in order to strengthen and uphold prevailing mutual trust. Thus the primary consideration has been given to the aspirations of the people rather than to Kashmir politics. The moderate stand of the two Premiers on the Kashmir issue was the indicator of their firm wishes to construct a friendly relationship between two countries. They firmly believed in a constructive relationship beyond the symbolisms, and both had explored the back channel diplomacy on Kashmir issue.

"The Foreign Secretaries of India and Pakistan signed a Memorandum of Understanding (MoU) on 21 February 1999, identifying measures aimed at promoting an environment of peace and security between the two countries". 9 The foreign ministers of India and Pakistan had planned a future course of relations. They were supposed to go through the back channel diplomacy to normalize the process. "On Pakistani side Niaz A. Naik, the former foreign secretary and R.K. Mishra from Indian side started the second - track diplomacy', ${ }^{10}$ The Lahore summit could be successful in making people-to-people contact easier. The Lahore summit was instrumental in sketching action plans to modify the travel restriction and to continue the composite dialogues between the foreign secretaries.

The Lahore initiatives in 1999 had a good prospect to solve the looming tensions between India and Pakistan. The Lahore summit was the result of the strong political willingness of the two Prime Ministers to solve the problems bilaterally, since they realized the critical situations and ground realities of the region. They expressed a strong conviction to take their countries on the path of prosperity and peace thereby willing to make South Asia a peaceful region.

\subsection{AGRA SUMMIT}

The historic Agra summit was held between Pakistan President Pervez Musharraf and Indian Prime Minister AtalBihari Vajpayee from 14-16 July 2001 at Agra. "The summit started with a highly expectation which would resolve all the disputes between the two countries including the five decade old Kashmir issue. "Both sides started the summit with hopefulness and in a spirit of goodwill; especially President Musharraf used the phrases "cautious optimism", "flexibility" and "open mind" to describe his buoyant views for the summit.

\footnotetext{
${ }^{7}$ Amjad Abbas Maggsi (n-d), pp.184.

${ }^{8}$ Amjad Abbas Maggsi.(n-d), pp.193
}

${ }^{9}$ Sumita Kumar, 1999, Indo-Pak bus diplomacy, pp.196.

${ }^{10}$ Amjad Abbas Maggsi.pp.195 
The Indian President also promised to take "bold and innovative" measures and to discuss the "core issue" between the two countries". 11

Agra summit was a modest beginning in the attempts to evolve a structure for a sustained dialogue process to embrace all the unresolved issues. The summit addressed the Kashmir issue, cross-border terrorism, nuclear risk reduction, release of prisoners of war, and commercial ties in various rounds of discussions. The opening remarks of the Indian Prime Minister A.B.Vajpayee during the first official meeting with the Pakistan President Mr. Pervez Musharraf contained a mention that issues such as poverty, hunger and depression were the core concerns of the people. Thus the summit gave a political space to address these issues with a multidimensional approach from both the governments of India and Pakistan.

The Indian Prime Minister A.B.Vajpayee clearly mentioned that poverty is the common enemy of India and Pakistan, and therefore the welfare of the people of both the nations is the primary objective of the Indian government. In this regard, both the nations could work together to eliminate the common threat of poverty. By the enhancement of economic ties and cooperation, they can well manage the problems of poverty of the people. The economic cooperation between the two nations will promote the exchange of goods beyond the boundaries and it would increase the trust level between the people. The economic cooperation and trade relations are the finest ways to increase trust level between the India and Pakistan, since trust deficit was the reasons for the failure of the peace processes between India and Pakistan. The summit has helped to some extent to find out the common problems and concerns to be addressed collectively by India and Pakistan, and it could improve the bilateral relations better, especially, after the nuclearisation of South Asia.

The procedural aspects of the summit were a failure because it was unsuccessful in drafting a conclusion, after being hit on two differences: one terrorism for India and another Kashmir for Pakistan. However, in a larger perspective, the summit gave an understanding that India and Pakistan can resolve their bilateral issues by mutual cooperation, and through continuous dialogues. The Agra summit transformed a bad weather situation into a favorable atmosphere for resuming bilateral dialogues between India and Pakistan.

\subsection{UNILATERAL CEASEFIRE IN KASHMIR}

The two-year deadlock after the failure of the Agra summit and the terrorist attack came to an end followed by India's peace initiatives in 2003, when the Indian Prime Minister A.B. Vajpayee announced the reversal policy with Pakistan. The political condition between India and Pakistan after the Agra failure was moving towards a warlike situation. Indian forces were alerted to go for war in any event on a short notice. The crisis got weakened after the U.S intervention, when the American President George W. Bush had sent his defense secretary Donald Rumsfeld and Richard Armitage to India and Pakistan. "Richard Armitage was successful in extracting the commitment from General Musharraf that Pakistan would end cross border infiltration permanently, which was conveyed to India', ${ }^{12}$ In response, India showed the readiness for partial withdrawal of her forces from the border and Arabian Sea. "The High Commissioners would be assigned again, over flights would be permitted, road and rail communications would be revived, cricket would be allowed, and dialogue would be resumed." ${ }^{13}$ As part of the peace initiative, India has taken a conscious effort and 'step by step' approach towards Pakistan to normalize the relations with Pakistan. "In consonance with this spirit, Prime Minister Vajpayee extended hand of friendship to Pakistan at a public rally in Srinagar on 18 April 2003', ${ }^{14}$ On 28 April 2003 Vajpayee had a conversation with his Pakistan counterpart Mir Zafarulla Khan Jamali. He discussed the importance of a conducive atmosphere between India and Pakistan before discussing any difficult issue. Further he suggested that the economic cooperation, cultural exchanges and people to people contact would facilitate a favorable platform for India and Pakistan to discuss the issues."This led to significant subsequent steps such as restoration of relations, at level of High Commissioners; resumption of the LahoreDelhi bus service, high level exchanges at the level of Parliamentarians, businessmen, media, artists, writers, Judges, peace activist, sporting contacts, and others; free medical treatment to 20 Pakistani children; release of prisoners and fishermen on both sides; and increase the strength of respective high commissioners'" ${ }^{15}$ These multilevel engagements have fostered the mutual trust and confidence, and generated a positive response from the people. In the very outset, India have been cautious about the desires of the peoples of both side to have a friendly and peaceful relation. Thus, the peace initiative is a reflection of India's responsibility towards the wishes of the common people.

\footnotetext{
${ }^{11}$ Makdoom AmenFaheem, 2004,www.storyofpakistan.com/Agra-summit-a-failure.

${ }^{12}$ Subhash Shukla, 2008, pp.904.

${ }^{13}$ Naibha Gul ,2007, pp.57

${ }^{14}$ Subash Shukla, 2008,pp. 904.

${ }^{15}$ Subash Shukla, 2008 pp.905. 
On 22 October 2003 India declared more steps to encourage people to people contact between India and Pakistan. The proposal includes-"resumption of the rail links; resumption of bilateral sporting encounters, including cricket, permission to senior citizens (65 years and above) to cross at Wagha on foot, holding visas camps in deferent cities to benefit the people,increasein the Delhi-Lahore-Delhi buses, establishment of the link

between the coast guard authorities, the non-arrest by either side of the fishermen of the other country with in the certain band on the sea, provision of free medical treatment to a second lot of 20 Pakistani children, resumption of passenger shipping service between Mumbai and Karachi, commencement of bus service between Srinagar and Muzzafarabad, starting a bus or rail link between Munabao in India and Khokrapur in Pakistan, and the increase in the size of the respective high commissioner', 16

On 23 November 2003 Pakistan responded positively towards India's peace initiative and gave an order to her armed forces to cease fire along the Line of control during the festival of Ramadan. "On November 19 2003, Indian Prime Minister AtalBihari Vajpayee announced that Indian troops would stop all offensive actions against Kashmiri separatist groups in Jammu and Kashmir during the Islamic month of Ramadan. While the military would remain "full alert against any attack," it would suspend combat operations as of 28 November 2003 " ${ }^{17}$ In the background of the Ceasefire, Indian government had a series of cultural and political contacts with various groups of Pakistan diplomats and Kashmir militants. "Backchannel contact between members of the National Security Advisory Board, representatives of Kashmiri dissident group were continued despite and even after the failure of the effort at a dialogue in July last', ${ }^{18}$ As a part of further developments the then Pakistan President showed an optimistic stand towards Indian readiness to resume the normal relations by inviting the then Indian Foreign Secretaries for conversations in September 2003. On 19 November 2003 Vajpayee announced a ceasefire in Jammu and Kashmir and ordered the Indian Armed Forces to stop all offensive actions in the borders. Later, on 2 December 2003, Pakistan also announced that her armed forces would exercise "maximum restraint" along the Line of Control.

The Indian government went extra miles even in unfavorable conditions to maintain peace in the IndiaPakistan border region. Vajpayee indicated on the 4December 2003 that he would be willing to extend the ceasefire beyond Ramadan if the ceasefire holds and meaningful negotiations commenced. Later, the ceasefire was extended thrice by Indian government to facilitate and encourage negotiations. Even though it was a political decision, the Ceasefire created an impact of cultural goodwill on the people on both the sides of the Line of Control. The decision of the Indian government to stop the military actions during the holy month of Ramadan had a great effect on the Muslim people in the both countries. The people of both countries welcomed the decisions with great hope that the ceasefire would solve the border issues even if it would take some time. Hence, the Ceasefire was a successful contribution both politically and culturally towards the normalization of the India-Pakistan relations.

\subsection{NEW PEACE PROPOSAL}

"The unprecedented steps, designed to reunite families and expand contacts between the two nations after five decades of conflict, were seen here as another step in keeping with the Indian prime minister's recent moves to jump-start peace initiatives". ${ }^{19}$ As part of India's peace initiatives Pakistan President Pervez Musharraf reciprocated the Indian proposal of 12 Confidence Building Measures. Both the nations agreed to each other's proposal and made some suggestions and changes respectively. A meeting was held between Prime Minister Vajpayee and President Musharraf on the sidelines of the SAARC, summit in Islamabad on 6 January 2004. They agreed to proceed further with normalization process and composite dialogues. The foreign secretaries held two rounds of talks from February 15 to 16 and December 27 to 28, 2004 respectively and all the two-year long indifference between India and Pakistan melted off to resume a warm relation. India proposed 12 CBMs given below.

1“ Resumption of talks to restore civil aviation links, including over flights.

1. Resumption of rail links following aviation links.

2. Resumption bilateral sports matches including Cricket.

3. Issuance of visas in cities outside the two countries' national capitals to shorten travel formalities.

4. Permission to individuals aged at least 65 years to cross in to India on foot. Previously only groups could walk across, while individual had to board bus.

5. Initiation of more buses in New Delhi-Lahore routes than now operate.

\footnotetext{
${ }^{16}$ Subash Shukla, pp.904.

${ }^{17}$ Sarath Kumara, 2000,https://www.wsws.org

${ }^{18}$ Chapter five mission Kashmir: respecting the verdict for peace, shodhganga.inflibnet.ac.in.pp.6.
}

${ }^{19}$ India offers Kashmir peace proposal. http://www.nbcnews.com, 10/22/2003.

DOI: $10.9790 / 0837-2204053139 \quad$ www.iosrjournals.org $\quad 37 \mid$ Page


6. Establishment of links between two country's' coastguard, before and after fishing season.

7. Preventing arrest of each other's fishermen within certain sea areas.

8. Provision of free medical treatment to 20 Pakistani children in India.

9. Increasing the staff of the their respective embassies

10. Consider a ferry service between Mumbai and Karachi.

11. Start of new bus services, one between Srinagar and Muzafarabad. The other would be bus or rail links between Khakrapur in Sindh and Munabao in Rajasthan', ${ }^{20}$

The proposed Confidence Building Measures (CBMs) were characterized by humanitarian approach and peoplecentric perspective. The re-opening of all kinds of transportation facilities at the boarders for individual above 65 years of age and easing of visa's restrictions are a major political breakthrough having significant impact on India and Pakistan's strained relationships. It had contributed to supplement the people-to-people contact. The noticeable feature of Confidence Building Measures was that they considered the emotions of the people to have more relationships across the borders. It would have facilitated the movements of the people across the borders of India and Pakistan, by the way of the trust levels they had achieved. "The advantage to India in providing greater access to Pakistani citizens to visit India is that this would create constituencies favoring Indo-Pak normalization of relations and enable them to perceive the benefits of democracy when they returned home to a military dictatorship". ${ }^{21}$ The understanding about the fishermen's problems has helped to reduce the arrest of fishermen within certain areas. By the way, the issues related to maritime disputes could be solved and they could improve the confidence of the fishermen. They realized the minds of people of India and Pakistan and resumed sports and games matches, especially cricket, because "cricket is the common love of the entire region, and has contributed to a feeling of unity for diversified nations.",22

\section{CONCLUSION}

Seventy years of India-Pakistan relation was characterized by various ups and downs that prolonged a lasting resolution to the hostilities of India and Pakistan. The inception of the continuum of ideological differences and divergent standpoints on various issues ignite out of Pakistan's claims over Kashmir region. The policy decision and approach of different Indian political parties in dealing the affairs with Pakistan were different in different eras of history. The Indian National Congress, a major party that ruled India since the Indian Independence for more than 45 years, most often as a single-party government, had always maintained a hardline policy on Kashmir issue that Pakistan must stop all the proxy war and cross border terrorism activities before attempting any peace initiative. On the other hand, the other short-lived Indian Central governments could not leave a long standing impressive mark or policy achievement in the case of dealing with the Kashmir issue. The A.B Vajpayee-led NDA government (1998-2004) was different in its approaches and policies regarding the India-Pakistan conflict. A. B Vajpayee, in his capacity as the Indian Prime Minister, adopted a flexible and popular stand in the Kashmir issue as opposed to the various Congress governments' uncompromised conventional attitude. He broke all the traditional approaches, and almost in every diplomatic move, continued single handed diplomatic strategic moves such as summits, ceasefire agreements, diplomatic initiatives, cricket diplomacy, even after the failures of Lahore and Agra summits. Though quite optimistic about his unilateral attempts to maintain peace between India and Pakistan, A.B Vajpayee did not hesitate to wage war against Pakistan in times of Kargil infiltration crisis.

Notable enough is the fact that A.B Vajpayee assumes the seat of the Indian Prime Minister at a crucial political moment when Kashmir issue and the struggle with Pakistan over other related issues were damaging India's all-complying political image and persona in the international South Asian political scenario. In spite of the fact that he was leading a jumbo-umbrella of a coalition government consisting more than 17 political parties as opposed to the single-party governments led by the Indian National Congress, Vajpayee's farsightedness, political will power, pragmatic viewpoint and visionary leadership proved instrumental in making significant advances in the attempt to address ideological differences, conflicts, and differences between India and Pakistan. Despite the differences and lack of support even within his own ministry, Vajpayee's courageous single handed

\footnotetext{
${ }^{20}$ Nabiha Gul, 2008, pp.12.

${ }^{21}$ PR Chari ,2003,

${ }^{22}$ ShakeelAhemed, ShahidKauser, 2007, pp.59.
} 
unilateral diplomatic measures have taken the conflicting nations a long way further in realizing mutual trust and understanding. The peace talks and non-military Confidence Building Measures have worked a great deal in instilling mutual faith among the people and rulers of both the nations, thereby reinstating the prestigious allcomplying political image of India in the South Asian region.

Analyzing the seventy years of India Pakistan relations, former Indian Prime Minister A.B Vajpayee had proved during his tenure in office that pragmatic diplomatic approach could win the situation rather than a conventional and traditional policy. He had carried out more initiatives on bilateral cooperation taking the engine of Indian diplomatic mechanism into confidence for a friendly relation with Pakistan. The Lahore declaration, visit to the Minar-e-Shareef and the introduction of Delhi-Lahore bus diplomacy were the signs of his understanding of a wider scope of Confidence Building Measures. His understanding about the wishes and feelings of the people benefitted him while dealing with Pakistan. Thus, this paper illustrates the significance of the paradigm shift in the Indian diplomatic strategy towards Pakistan during the tenure of first A.B Vajpayee-led NDA government and the advancement in peace initiatives realized utilizing non-military confidence building measures. If the India central governments that succeed the first NDA government take the Indian diplomatic mechanism into confidence and uphold national interest while dealing with Pakistan displaying exemplary political will power to adopt pragmatic initiatives giving up conventional rigid-old policies the advancement in the lines of Vajpayee method, it would help in betterment of the relationship between India and Pakistan. Such political will power and strategical will power would help India reinstate her position as an influential goodwill ambassador and power center in South Asian political scenario adding up to her national prestige and honor among the international community.

\section{REFERENCES}

[1] United Nation Centre for Disarmament Report of the secretary General, Comprehensive Study on Confidence-building Measure, Department of Political Science and Security Council Affairs, 1996.pp, 120.

[2] Mohammed Badrul Alam, In Pursuit of Peace: A Micro Study of Confidence-Building Measures between India and Pakistan, Indian Journal of Asian Affairs, 23(1/2), 2010, 41-60.

[3] Satpal, India -Pakistan Peace Process: An Analysis, Golden Research Thoughts International Multidisciplinary Research Journal. Vol. 4 (3),2014, 1-7.

[4] Sumita Kumar, Indo-Pak bus diplomacy, Strategic Analysis, 23(1), 1999, 167-170.

[5] Amjad Abbas Maggsi, Lahore Declaration February 1999 A Major Initiative for Peace in South Asia, Pakistan Vision, 14(1), nd,pp.183-201.

[6] Ayanjit Sen, India-Pakistan buses close down, BBC News. December 28, 2001.

[7] Makdoom Amen Faheem, Agra summit a failure, edit in Story of Pakistan a multimedia journey, 2004,http://storyofpakistan.com/Agra-summit-a-failure

[8] Subhash Shukla Indo-Pak relations, Gujral to Manmohan Singh, The Indian Journal of Political Science, 69(4), 2008, pp.897-910.

[9] Naibha Gul, Pakistan -India peace process-1990-2007 An Appraisal, Pakistan Horizon, Pakistan foreign policy Analysis. Pakistan Institute of International Affairs, 60. (2), 2007, PP.47-64.

[10] Sarath Kumara, A renewed diplomatic push for negotiations over Kashmir,International Committee of the Fourth International, World Socialist web site wsw.org,2000.

[11] Chapter five, respecting the verdict for peace, Shodhganga.inflibnet.ac.in.pp.181-221,

[12] India offers Kashmir peace proposal. www.nbcnews.com,10/22/2003.

[13] Nabiha Gul, Pakistan-India Composite Dialogue, Pakistan Institute of International Affairs, Pakistan Horizon, 61(3), 2008, pp.11-17.

[14] P.R. Chari, India's New Peace Initiative, Institute of Peace and Conflict Studies, 2003

[15] ShakeelAhemed, ShahidKauser, Cricket for politics and peace; from 1987 to 2007 cricket world cup between India and Pakistan, International journal science ,culture and sports, 3(4), 2015,pp.59-66. 